\title{
OPTIMIZATION OF THE RECIPE COMPOSITION OF JELLY MARMALADE WITH REDUCED CONTENT OF SUGAR
}

\author{
D. Matias, J. Kambulova, A. Dorokhovich, I. Mandzyuk \\ National University of Food Technologies
}

\begin{tabular}{l}
$\quad$ Key words: \\
Marmalade \\
Sucrose \\
Glucose \\
Fructose \\
Optimization \\
Recipe \\
Energy valu \\
\hline
\end{tabular}

Article history:

Received 04.07.2018

Received in revised form

26.07.2018

Accepted 16.08.2018

Corresponding author:

D. Matias

E-mail:

npnuht@ukr.net

\begin{abstract}
The peculiarity of marmalade products, as well as the whole group of sugar confectionery products, is high content of sugar. Taking into account the modern requirements of nutrition science, the direction of reducing sugar content or the creation of products without it is one of the priority areas of food industry.

The paper analyzes the current state of production of low calorie marmalade and proves the relevance of the development of jelly marmalade with reduced sugar content and improved nutritional value. The data about the optimization of the recipe composition of jelly marmalade with reduced content of saccarose, glucose, fructose with agar polysaccharides and different types of pectin is presented. Solutions include reduction of the quantity of sugars to the limits, which provides a sweet taste of the products; introduction of polydextrose, as an inert filler, for regulating the content of dry matter and the structural and mechanical properties of marmalade in an amount equal to the amount of sugar excluded from the recipe; introduction of fruit and vegetable purees in an amount from 15 to $25 \%$ by weight, to provide a natural rich color, pleasant taste and aroma of finished products.

According to the obtained data, it is established that all the optimal ratios of the recipe components for varieties of marmalade will give the opportunity to receive finished products with a strength that is not inferior to products made according to traditional recipes. At the same time, the energy value for all samples is reduced by $25 \%$ on average. The developed recipes are approved in the established order by the Industry Tasting Commission, new types of jelly marmalade were noted at the tasting contests.
\end{abstract}

DOI: $10.24263 / 2225-2924-2018-24-4-25$

\section{ОПТИМІЗАЦІЯ РЕЦЕПТУРНОГО СКЛАДУ ЖЕЛЕЙНОГО МАРМЕЛАДУ 3 ПОНИЖЕНИМ ВМІСТОМ ЦУКРУ}

\author{
Д.С. Матяс, Ю.В. Камбулова, А.М. Дорохович, І.В. Мандзюк \\ Національний університет харчових технологій
}

Особливістю мармеладних виробів, як $і$ всієї групи иукристих кондитерських виробів, є великий вміст иукру. Враховуючи сучасні вимоги науки про хар- 
чування, спрямування технологічних схем продукцї на зниження вмісту цукру або створення виробів без нього є одним з пріоритетних напрямків галузі.

У статті проаналізовано сучасний стан виробництва низькокалорійного мармеладу та доведено актуальність розроблення мармеладу желейного зі зниженою цукромісткістю та покращеною харчовою цінністю. Наведено дані оптимізації рецептурного складу желейного мармеладу з пониженим вмістом сахарози, глюкози, фруктози на агарових полісахаридах і пектинах. Рішення передбачають зменшення рецептурної кількості цукрів до меж, за якими забезпечується солодкий смак виробів; введення полідекстрози як інертного наповнювача для регулювання вмісту сухих речовин і структурномеханічних властивостей мармеладу в кількості, рівночінній кількості иукру, щуо виключено із рецептури; внесення фруктово-овочевих пюре в кількості від 15 до 25\%, для забезпечення натурального насиченого кольору, присмного смаку та аромату готової продукиії.

Згідно з отриманими даними всі оптимальні співвідношення рецептурних компонентів для різновидів мармеладу дадуть можливість отримувати готову продукцію з міцністю, щзо не поступається виробам, виготовленим за традиційними рецептурами. При цзьому енергетична цінність для всіх зразків y середньому зменшується на 25\%. Розроблені рецептури затверджені в установленому порядку галузевою Дегустаційною комісією, нові види мармеладу желейного були відзначені на дегустаційних конкурсах.

Ключові слова: мармелад, сахароза, глюкоза, фруктоза, оптимізачія, рецептура, енергетична иінність.

Постановка проблеми. Кондитерськими підприємствами України випускається доволі широкий спектр мармеладних виробів. Здебільшого це група желейного мармеладу, який має привабливий зовнішній вигляд, різноманітну форму, приємний запах і смак, достатньо простий у виготовленні. Саме тому він популярний серед населення і виробничників. Традиційними рецептурами мармеладу передбачено використання $50 \ldots 70 \%$ цукру білого, штучних барвників, ароматизаторів [1], що особливо насторожує, оскільки основними споживачами виробів $є$ діти і підлітки. Тому розроблення низькокалорійних солодощів, внесення натуральних смакоароматичних речовин, додавання функціональних інгредієнтів на сьогодні є актуальним напрямком розвитку кондитерського виробництва.

Аналіз останніх досліджень і публікацій. Світова популяризація здорового харчування і рекомендації медиків щодо обмеження споживання цукрів розширюють асортимент продукції із заміною цукру. До того ж починають змінюватись світові підходи до технологій кондитерських виробів. Низка потужних корпорацій запровадила в асортиментному ряді продукцію з частковою або повною заміною цукрів. Наприклад, бельгійська компанія Callebaut [2] пропонує вибір делікатного темного і білого шоколаду із заміною сахарози на мальтитол як підсолоджувача, а також фісташкової, рідкої горіхової паст зі зниженим (на 50\%) вмістом цукру. 
Lanouba - бельгійська компанія налагодила випуск «Преміум колекції насолод sugarfree» [3] із хрустких вафель, шоколаду, шоколадних батончиків, маршмелоу, джемів, які не містять жиру й цукру і практично не містять вуглеводів.

Іспанська компанія Intervan [4] — одна 3 визнаних на європейському ринку виробників цукерок, випускає спеціальну лінійку льодяників без цукру (бренди Pictolin i Cafe Dry) з натуральним цукрозамінником ізомальтом.

Із 1972 p. на ринку США і у більш ніж 50 країнах світу представляє свою продукцію компанія Walden Farms - провідний виробник дієтичних продуктів. Компанія одна з перших, яка започаткувала виробництво корисних продуктів з низьким рівнем жирності та простих цукрів. Сьогодні вся продукція, що виробляється під цим брендом, не містить жирів, цукрів та глютенів, а також підходить для вегетаріанців і людей, що страждають алергією [5].

Показовим прикладом масштабного зменшення кількості цукру $є$ діяльність світової компанії Nestle (Франція), яка у 2007 р. ввела обов'язкову політику щодо постійного зниження рівня цукру, особливо в продуктах, які суттєво впливають на загальний обсяг його споживання. Як результат, у період 3 2000 р. по 2015 р. компанія зменшила загальний вміст цукру в продукції на $38 \%$. Окрім цього, технологи підприємств в рецептурах виробів намагаються використовувати обмежену кількість підсолоджувачів [6]. Також компанія заявила про використання з 2018 р. спеціально структурованого цукру [7], який дасть змогу зберегти солодкість за менших його концентрацій. Вчені стверджують, що нова сировина виглядає і смакує як цукор, але його модифікована структура суттєво сповільнює розклад цукру в організмі і калорії поступають лише при його повному перетравленні.

Cargill (США) пропонує вирішення проблеми розробки продуктів зі зниженим вмістом цукру шляхом додавання безкалорійних або низькокалорійних підсолоджувачів, які пропонують виробникам у широкому асортименті [8].

На кондитерському ринку України останнім часом значно збільшився попит на вироби з низьким вмістом цукру, виготовлених із натуральних та екологічно чистих інгредієнтів. Серед виробників «корисних кондитерських виробів» можна виділити такі торговельні марки: «СAME», «COOKIETONE», «Жива кухня», «Фрукта», «Ай да Бейкер». Українська компанія Гудвіл-Інвест виробляє високоякісний трав'яний безкалорійний цукрозамінник - стевію у вигляді таблеток, стіків, в порошку, а також шоколадні напої зі стевією [9].

У наукових працях активно досліджуються питання вилучення цукрів із складу кондитерських виробів і зменшення їх енергетичної цінності присвятили свої роботи вчені, можливість застосовування солодких речовин у рецептуpax кондитерських виробів без цукру (підсолоджувачів з високим і низьким цукровим еквівалентом, харчових волокон, цукрозамінників; практично безкалорійних, низькокалорійних, висококалорійних; штучних і натуральних), застосування різноманітної фруктово-ягідної, овочевої сировини для зменшення рівня цукру, внесення харчових продуктів - носіїв солодкого смаку тощо.

Науковцями Національного університету харчових технологій [10] запропоновано технологію желейного мармеладу на пектині та к-каррагінані зниженої 
глікемічності зі статусом «функціональний продукт» шляхом використання на заміну цукру білого поєднання цукрозамінників низької глікемічності (лактитолу) і цукрів (фруктози), ФФСІ: вітаміну С (аскорбінова кислота), молока та молокопродуктів.

Вченими Одеської національної академії харчових технологій [11] удосконалено рецептуру двошарового желейно-збивного мармеладу за рахунок використання крохмальних сиропів, фруктози та полідекстрози. На основі проведених досліджень було розроблено рецептури мармеладу зі зниженою цукромісткістю і глікемічністю.

Дослідниками з Чорногорії розроблено низькокалорійний мармелад (lowcalorie marmelade) шляхом використання низькоетерифікованого амідованого пектину та зниженим на 42,0-50,0\% вмістом цукру [12]. Вченими Єгипту запатентовано низькокалорійний мармелад на основі пюре з апельсину, гарбуза та папаї за умови заміни сахарози фруктозою, стевіозидом та сукралозою.

Тож світові й українські компанії, лідери ринку кондитерської продукції починають випуск виробів 3 повним вилученням цукру за рахунок використання підсолоджувачів або цукрових спиртів - поліолів, які віднесені Комісією Кодекс Аліментаріус також до підсолоджувачів. На сьогодні норма споживання кожного підсолоджувача регламентована, вони заборонені до споживання дітям. Тому існує потреба у раціоналізації вмісту цукрів у діючих рецептурах кондитерських виробів, в тому числі й мармеладі, з метою його використання лише для надання солодкого смаку. Покращення структурно-механічних показників якості мармеладу, які зміняться за вилучення цукрів, можливо за рахунок внесення харчових волокон, інертних наповнювачів, що випускаються крохмале-патоковою промисловістю.

Мета дослідження: оптимізація рецептурного складу мармеладу желейного зі зниженим вмістом цукрів (цукру білого кристалічного, глюкози, фруктози), об'ємним наповнювачем полідекстрозою, асортиментом ягідного і овочевого пюре.

Викладення основних результатів дослідження. Можливість зменшення цукру білого кристалічного, глюкози і фруктози при формуванні драглеподібної структури желейного мармеладу на різних гідроколоїдах — агарі і к-каррагінані, H- i L-пектинах — встановлювали за органолептичними показниками і загальною деформацією сформованого драглю мармеладу. Для визначення готували зразки мармеладу із повною заміною цукру білого традиційної рецептури на глюкозу і фруктозу (з урахуванням вмісту СР). Для контрольної рецептури на агарі і к-каррагінані використано рецептуру мармеладу «Желейний формовий» на агарі [13]. Для контрольної рецептури на пектинах використано рецептуру мармеладу «Желейний формовий» 3 використанням H-пектину [13]. Вміст L-пектину варіювали відповідно до встановленого оптимального його дозування: $1,2 \% \mathrm{H}$-пектину : $2 \% \mathrm{~L}$ пектину. Дослідження проводили на структурометрі СТ-1 (початкова сила дотику $F_{0}=0,5 \mathrm{H}$, сила навантаження, $F-6 \pm 0,5 \mathrm{H}$ ) [14]. Допустиму межу зменшення цукрів встановлювали за відчуттям солодкості. Додатково спостерігали за зміною міцності мармеладного драглю. Результати визначення допустимих меж зменшення цукрів надані в табл. 1. 
Представленими в таблиці даними підтверджується закономірність, що зменшення вмісту цукрів призводить до урівноваження солодкості виробів. Дійсно, в мармеладних масах на будь-якому драглеутворювачі з сахарозою або глюкозою виріб залишається солодким до вмісту цукру в рецептурі 35 г/100 г продукту, а в мармеладних масах 3 фруктозою - до 20-25 г/100 г продукту. Зменшення цукрів позначається й на формуванні структурномеханічних властивостей [15].

Таблиия 1. Визначення допустимих меж зменшення цукрів у желейному мармеладі

\begin{tabular}{|c|c|c|}
\hline $\begin{array}{l}\text { Кількість цукру, } \\
\text { г/100 г } \\
\text { готового продукту }\end{array}$ & Відчуття солодкості & $\begin{array}{c}\text { Загальна деформація, } \\
\text { \% }\end{array}$ \\
\hline 1 & 2 & 3 \\
\hline \multicolumn{2}{|c|}{ Агар, сахароза } & \\
\hline Контроль, 60 г/ 100 г & надмірно солодкий & 6,70 \\
\hline $55 \Gamma / 100 г$ & надмірно солодкий & 6,80 \\
\hline $45 \Gamma / 100$ г & добре солодкий & 6,90 \\
\hline $35 \Gamma / 100$ г & солодкий & 7,23 \\
\hline $25 \Gamma / 100 \Gamma$ & помірно солодкий & 8,47 \\
\hline \multicolumn{2}{|c|}{ Агар, глюкоза } & \\
\hline Контроль, 60 г/ 100 г & надмірно солодкий & 7,43 \\
\hline $55 \Gamma / 100 \Gamma$ & надмірно солодкий & 8,10 \\
\hline $45 \Gamma / 100$ г & солодкий & 8,30 \\
\hline $35 \Gamma / 100 \Gamma$ & помірно солодкий & 8,40 \\
\hline $25 \Gamma / 100 \Gamma$ & не солодкий & 8,70 \\
\hline \multicolumn{2}{|c|}{ Агар, фруктоза } & \\
\hline Контроль, 60 г/ 100 г & надмірно солодкий & 9,33 \\
\hline $55 \Gamma / 100 г$ & надмірно солодкий & 9,87 \\
\hline $45 \Gamma / 100 г$ & надмірно солодкий & 10,00 \\
\hline $35 \Gamma / 100 г$ & надмірно солодкий & 10,10 \\
\hline $25 \Gamma / 100 \Gamma$ & солодкий & 10,33 \\
\hline \multicolumn{2}{|c|}{ К-каррагінан, сахароза } & \\
\hline Контроль, 60 г/ 100 г & надмірно солодкий & 10,47 \\
\hline $55 \Gamma / 100 \Gamma$ & надмірно солодкий & 11,00 \\
\hline $45 \Gamma / 100 \Gamma$ & солодкий & 12,97 \\
\hline $35 \Gamma / 100 \Gamma$ & помірно солодкий & 14,57 \\
\hline $25 \Gamma / 100 \Gamma$ & не солодкий & 17,57 \\
\hline \multicolumn{2}{|c|}{ К-каррагінан, глюкоза } & \\
\hline Контроль, 60 г/ 100 г & надмірно солодкий & 11,33 \\
\hline $55 \Gamma / 100 \Gamma$ & надмірно солодкий & 14,73 \\
\hline $45 \Gamma / 100 \Gamma$ & солодкий & 16,37 \\
\hline $35 \Gamma / 100$ г & помірно солодкий & 17,57 \\
\hline 25 г/ 100 г & не солодкий & 18,17 \\
\hline \multicolumn{2}{|c|}{ К-каррагінан, фруктоза } & \\
\hline Контроль, 60 г/ 100 г & надмірно солодкий & 12,67 \\
\hline $55 \Gamma / 100 \Gamma$ & надмірно солодкий & 14,00 \\
\hline $45 \Gamma / 100$ г & надмірно солодкий & 16,33 \\
\hline $35 \Gamma / 100 \Gamma$ & солодкий & 17,23 \\
\hline
\end{tabular}


ХАРЧОВІ ТЕХНОЛОГЇ̈

\begin{tabular}{|c|c|c|}
\hline \multicolumn{3}{|c|}{ Продовження табл. 1} \\
\hline 1 & 2 & 3 \\
\hline $25 \Gamma / 100 \Gamma$ & солодкий & 18,70 \\
\hline \multicolumn{3}{|c|}{ Н-пектин, сахароза } \\
\hline Контроль, 60 г/ 100 г & надмірно солодкий & 16,47 \\
\hline $35 \Gamma / 100 \Gamma$ & солодкий & 20,83 \\
\hline $25 \Gamma / 100 \Gamma$ & не солодкий & 21,1 \\
\hline \multicolumn{3}{|c|}{ Н-пектин, глюкоза } \\
\hline Контроль, 60 г/ 100 г & надмірно солодкий & 18,83 \\
\hline $35 \Gamma / 100 \Gamma$ & помірно солодкий & 20,60 \\
\hline $25 \Gamma / 100 \Gamma$ & не солодкий & 26,00 \\
\hline \multicolumn{3}{|c|}{ Н-пектин, фруктоза } \\
\hline Контроль, 60 г/ 100 г & надмірно солодкий & 25,97 \\
\hline $35 \Gamma / 100 \Gamma$ & надмірно солодкий & 28,53 \\
\hline $25 \Gamma / 100 \Gamma$ & солодкий & 31,03 \\
\hline \multicolumn{3}{|c|}{ L-пектин, сахароза } \\
\hline Контроль, 50 г/ 100 г & солодкий & 41,90 \\
\hline $35 \Gamma / 100 \Gamma$ & солодкий & 54,17 \\
\hline $20 \Gamma / 100 \Gamma$ & помірно солодкий & 63,37 \\
\hline \multicolumn{3}{|c|}{ L-пектин, глюкоза } \\
\hline Контроль, 50 г/ 100 г & надмірно солодкий & 49,80 \\
\hline $35 \Gamma / 100 \Gamma$ & солодкий & 53,20 \\
\hline $20 \Gamma / 100 \Gamma$ & не солодкий & 59,63 \\
\hline \multicolumn{3}{|c|}{ L-пектин, фруктоза } \\
\hline Контроль, 50 г/ 100 г & надмірно солодкий & 43,57 \\
\hline $35 \Gamma / 100 \Gamma$ & надмірно солодкий & 45,90 \\
\hline $20 \Gamma / 100 \Gamma$ & солодкий & 51,77 \\
\hline
\end{tabular}

Поступове зменшення його рецептурної кількості відображається на збільшенні показника загальної деформації. Це обгрунтовує введення до рецептури мармеладу речовин, що покращуватимуть структуру мармеладу й забезпечуватимуть необхідний вміст сухих речовин виробу.

Для корегування структурно-механічних властивостей готового мармеладу, відновлення вмісту сухих речовин доцільним, на нашу думку, є застосування інертного наповнювача - полідекстрози. Вперше науково обгрунтовано використання полідекстрози для регулювання структурно-механічних властивостей мармеладу на агарі і пектині у [16]. Успішний досвід відновлення структури мармеладних мас 3 пониженим вмістом цукрів може бути використаний і на даних дослідних системах мармеладу. Полідекстроза полісахарид, отриманий гідролізом крохмалю, використовується як наповнювач для мас без цукру, жиру. Володіє властивостями харчових волокон $\mathrm{i}$ пребіотика, має низький глікемічний індекс. Полісахарид має високу загущувальну здатність, ледь солодкуватий присмак, що не відобразиться на смаку готової продукції. Оскільки полідекстроза є інертним наповнювачем, ії кількість у рецептурах складала аналогічну кількість цукру, що виводиться із рецептури.

Під час проведення досліджень щодо встановлення раціональної кількості глюкози в мармеладі відмічений негативний процес іiі кристалізації, що 
призводить до зацукрювання виробу й унеможливлює іiі споживання. Дійсно, головним негативним фактором, що обмежує застосування глюкози в цукристих кондитерських виробах, $є$ іiі швидка кристалізація в перенасичених розчинах [17]. Попередніми дослідженнями 3'ясовано, що в процесі зберігання мармеладних мас як на агарових полісахаридах, так і на пектинах, вміст глюкози в яких перевищує 70\%, спостерігається випадіння кристалів. Запобігти цьому явищу можливо додаванням антикристалізаторів. Найбільш застосовуваними кондитерською промисловістю антикристалізаторами є крохмальна патока. Після дослідження впливу різних видів патоки [18] встановлено, що для запобігання кристалізації глюкози при уварюванні мармеладних мас доцільно використовувати патоку мальтозну, з низьким вмістом глюкози у складі редукувальних речовин, у співвідношенні глюкоза:мальтозна патока як 1:(0,7 ...0,9). У процесі зберігання додатково відмічено, що всі дослідні зразки мармеладу не адсорбують вологу 3 повітря, не «розмокають» у процесі зберігання, що пов'язано з низькою сорбційною здатністю глюкози. Отже, даний вид патоки і встановлені його концентраційні співвідношення рекомендували для подальшого оптимізування рецептур желейного мармеладу на глюкозі.

Також вважаємо необхідним рекомендувати до введення в рецептури мармеладу фруктові й овочеві пюре, що випускається консервною промисловістю в доволі широкому асортименті. Це урізноманітнить смакову й кольорову гаму мармеладу без використання штучних барвників, збагачуватиме його хімічний склад цінними біологічно-активними речовинами. Для оптимізації використано кизилове, обліпихове, тернове, малинове, полуничне, ожинове, гарбузове, червоної та чорної смородини пюре.

Для визначення оптимальних рецептурних співвідношень запропонованих рецептурних компонентів обрано метод багатофакторного експерименту. За критерій оптимальності визначили міцність драглю мармеладу $(\mathscr{V})$; оптимізувальними факторами обрали: кількість цукру (сахарози, глюкози, фруктози) $\left(X_{1}\right)$, г; кількість пюре $\left(X_{2}\right)$, г; кількість кислоти (молочної, лимонної) $\left(X_{3}\right), \mathrm{cm}^{3}$. Технологічний процес одержання мармеладної маси принципово не відрізнявся від традиційного, за винятком додавання сухої карамельної патоки на заміну рідкої. Таке технологічне рішення прийнято 3 метою спрощення технологічного процесу підготовки патоки й транспортування іiі на етап приготування рецептурної суміші, що супроводжується позитивним зменшенням енергоресурсів. Розраховані кількості цукру, структуроутворювача, патоки, полідекстрози змішували, додавали воду із розрахунку «суміш:вода» як $1: 80 \ldots 100$ і розчиняли за температури $95 \ldots 100^{\circ} \mathrm{C}$ протягом $15 \ldots 20$ хв (для приготування мармеладних мас на агарі здійснювали попереднє набухання агару протягом 30-60 хв, після чого нагрівали його до повного розчинення i у розчин вносили заздалегідь приготовлену суху суміш). Сироп уварювали до вмісту СР 80\%, охолоджували до температури $90^{\circ} \mathrm{C}$, вводили згущене пюре i кислоту, перемішували і відливали зразки мармеладу. Для Н-пектину мармеладну масу не охолоджували, а смакові компоненти вводили відразу після уварювання. Готовий виріб зберігався 24 год для повного драглеутворення. Параметри оптимізації, на прикладі мармеладу на агарі, наведені в табл. 2. 
ХАРЧОВІ ТЕХНОЛОГЇ̈

Таблиия 2. Параметри оптимізації рецептурного складу мармеладу на агарі

\begin{tabular}{|c|c|c|c|c|c|c|c|c|}
\hline Параметри & \multicolumn{8}{|c|}{ Значення параметрів } \\
\hline \multicolumn{9}{|c|}{ Агар-сахароза-терен «Терновий» } \\
\hline $\begin{array}{l}\text { Кількість цукру } \\
\text { білого криста- } \\
\text { лічного }\left(X_{1}\right), \text { г }\end{array}$ & 41,62 & 36,08 & 41,62 & 36,08 & 41,62 & 36,08 & 41,62 & 36,08 \\
\hline $\begin{array}{c}\text { Кількість пюре } \\
\text { терну }\left(X_{2}\right), \Gamma\end{array}$ & 9,6 & 9,6 & 4,8 & 4,8 & 9,6 & 9,6 & 4,8 & 4,8 \\
\hline $\begin{array}{l}\text { Кількість кислоти } \\
\text { молочної }\left(X_{3}\right), \mathrm{cm}^{3}\end{array}$ & 2,5 & 2,5 & 2,5 & 2,5 & 1,5 & 1,5 & 1,5 & 1,5 \\
\hline $\begin{array}{l}\text { Міцність марме- } \\
\text { ладу, }(У), \text { КПа }\end{array}$ & 30,05 & 28,45 & 29,90 & 35,70 & 26,09 & 26,92 & 26,14 & 28,95 \\
\hline \multicolumn{9}{|c|}{ Агар-глюкоза-кизил «Кизиловий» } \\
\hline $\begin{array}{c}\text { Кількість глюкози } \\
\left(X_{1}\right), \Gamma\end{array}$ & 51,02 & 46,66 & 51,02 & 46,66 & 51,02 & 46,66 & 51,02 & 46,66 \\
\hline $\begin{array}{c}\text { Кількість } \\
\text { кизилового пюре } \\
\left(X_{2}\right), \text { г } \\
\end{array}$ & 11,2 & 11,2 & 5,6 & 5,6 & 11,2 & 11,2 & 5,6 & 5,6 \\
\hline $\begin{array}{l}\text { Кількість кислоти } \\
\text { молочної }\left(\mathrm{X}_{3}\right), \mathrm{cm}^{3} \\
\end{array}$ & 2,5 & 2,5 & 2,5 & 2,5 & 1,5 & 1,5 & 1,5 & 1,5 \\
\hline $\begin{array}{c}\text { Міцність } \\
\text { мармеладу, кПа }\end{array}$ & 28,20 & 34,00 & 25,13 & 27,32 & 31,48 & 29,37 & 27,69 & 28,70 \\
\hline \multicolumn{9}{|c|}{ Агар-фруктоза-обліпиха «Обліпиховий» } \\
\hline $\begin{array}{c}\text { Кількість фруктози } \\
\left(X_{1}\right), \Gamma\end{array}$ & 46,72 & 42,73 & 46,72 & 46,72 & 46,72 & 42,73 & 46,72 & 42,73 \\
\hline $\begin{array}{l}\text { Кількість пюре } \\
\text { обліпихи }\left(X_{2}\right), \text { г }\end{array}$ & 10,6 & 10,6 & 5,3 & 5,3 & 10,6 & 10,6 & 5,3 & 5,3 \\
\hline $\begin{array}{l}\text { Кількість кислоти } \\
\text { молочної }\left(X_{3}\right), \mathrm{cm}^{3}\end{array}$ & 2,5 & 2,5 & 2,5 & 2,5 & 1,5 & 1,5 & 1,5 & 1,5 \\
\hline $\begin{array}{c}\text { Міцність } \\
\text { мармеладу, кПа }\end{array}$ & 28,20 & 27,40 & 24,63 & 27,02 & 29,25 & 31,48 & 26,02 & 28,70 \\
\hline
\end{tabular}

За допомогою статистичного методу середніх значень розраховано коефіцієнти рівнянь, які описують процес драглеутворення мармеладу. За критерієм Стьюдента визначено значимість коефіцієнтів і отримано системи рівнянь регресії в кодованому вигляді:

- для системи «агар-сахароза-терен», мармелад «Терновий»:

$$
y=29,03-0,98 x_{1}+1,15 x_{2}+2,0 x_{3}+1,17 x_{1} \cdot x_{2} ;
$$

- для системи «агар-глюкоза-кизил», мармелад «Кизиловий»:

$$
y=28,98-0,98 x_{1}+1,02 x_{2}+1,17 x_{1} \cdot x_{3} ;
$$

- для системи «агар-фруктоза-обліпиха», мармелад «Обліпиховий»:

$$
y=27,84-0,81 x_{1}+1,25 x_{2}-1,03 x_{3} ;
$$

- для системи «к-каррагінан-сахароза-кизил», мармелад «Кизилова насолода»:

$$
y=28,92-2,55 x_{1}+2,54 x_{3}-2,38 x_{1} \cdot x_{2} ;
$$

- для системи «к-каррагінан-глюкоза-терен», мармелад «Лісова слива»:

$y=22,10-4,67 x_{1}+5,2 x_{2}+3,1 x_{3}+5,32 x_{1} \cdot x_{2}-3,02 x_{1} \cdot x_{3}-5,78 x_{2} \cdot x_{3} ;$ 
- для системи «к-каррагінан-фруктоза-обліпиха», мармелад «Обліпиховий вогник»:

$$
y=26,20-6,06 x_{1}+0,22 x_{2}+6,02 x_{3} ;
$$

- для системи «Н-пектин-фруктоза-чорна смородина», мармелад «Чорносмородиновий»:

$$
y=28,03+3,37 x_{1}+2,32 x_{3}-2,38 x_{1} \cdot x_{2}+3,15 x_{1} \cdot x_{3}
$$

- для системи «Н-пектин-сахароза-червона смородина», мармелад «Червоносмородиновий»:

$$
y=28,03+3,37 x_{1}+2,32 x_{3}-1,34 x_{1} \cdot x_{2}+3,15 x_{1} \cdot x_{3}
$$

- для системи «Н-пектин-глюкоза-гарбуз», мармелад «Сонячний»:

$$
y=24,79+1,09 x_{1}-2,75 x_{3}+2,1 x_{1} \cdot x_{3}+1,65 x_{2} \cdot x_{3} ;
$$

- для системи «L-пектин-сахароза-полуниця», мармелад «Полуничний»:

$$
y=23,71-2,78 x_{1}-1,62 x_{3}+1,19 x_{1} \cdot x_{3}+1,17 x_{1} \cdot x_{2} \cdot x_{3} ;
$$

- для системи «L-пектин -глюкоза-малина», мармелад «Малиновий»:

$$
y=23,65-2,77 x_{1}-1,60 x_{3}+1,13 x_{1} \cdot x_{3} ;
$$

- для системи «L-пектин-фруктоза-ожина», мармелад «Ожиновий»:

$$
y=23,25-1,52 x_{1}-1,2 x_{3} .
$$

За результатами оптимізації визначили найкращі співвідношення рецептурних компонентів різних видів мармеладу, що представлені в табл. 3. Згідно з представленими результатами, всі наведені оптимальні співвідношення рецептурних компонентів для різновидів мармеладу дадуть можливість отримувати готову продукцію з міцністю, що не поступається контрольним зразкам. Наприклад, міцність мармеладу желейного на агарі, виготовленого за традиційною рецептурою, складає 32 кПа, а мармеладу 3 пониженим вмістом сахарози - 35,5 кПа, глюкози - 34,1 кПа, фруктози - 31,5 кПа. Міцність мармеладу на к-каррагінані з пониженим вмістом сахарози - 31,2 кПа, глюкози і фруктози - 31,0 кПа.

Таблиця 3. Зони оптимальних значень рецептурного складу мармеладу 3 пониженим вмістом цукрів

\begin{tabular}{|c|c|c|c|c|}
\hline Назва зразку & $\begin{array}{c}\text { Кількість } \\
\text { цукру, } \\
\left(X_{1}\right), \Gamma\end{array}$ & $\begin{array}{c}\text { Кількість } \\
\text { пюре, } \\
\left(X_{2}\right), \Gamma\end{array}$ & $\begin{array}{c}\text { Кількість } \\
\text { кислоти, } \\
\left(X_{3}\right), \mathrm{cm}^{3}\end{array}$ & $\begin{array}{c}\text { Міцність } \\
\text { мармеладу, } \\
\left(Y_{1}\right), \text { кПа }\end{array}$ \\
\hline 1 & 2 & 3 & 4 & 5 \\
\hline $\begin{array}{c}\text { Контроль «Желейний формовий» } \\
\text { на агарі }\end{array}$ & 67,0 & - & 2,2 & 32,0 \\
\hline Агар-сахароза-терен «Терновий» & 36,09 & 9,60 & 2,0 & 35,5 \\
\hline Агар-глюкоза-кизил «Кизиловий» & 46,72 & 10,80 & 2,0 & 34,1 \\
\hline $\begin{array}{c}\text { Агар-фруктоза-обліпиха } \\
\text { «Обліпиховий» }\end{array}$ & 42,79 & 10,63 & 1,5 & 31,5 \\
\hline $\begin{array}{c}\text { К-каррагінан-сахароза-кизил } \\
\text { «Кизилова насолода» }\end{array}$ & 36,05 & 8,00 & 2,0 & 31,2 \\
\hline
\end{tabular}




\begin{tabular}{|c|c|c|c|c|}
\hline \multicolumn{5}{c}{ Продовженя табл. 3 } \\
\hline $\begin{array}{c}\text { К-каррагінан-глюкоза-терен } \\
\text { «Лісова слива» }\end{array}$ & 45,89 & 9,20 & 2,0 & 31,0 \\
\hline $\begin{array}{c}\text { К-каррагінан-фруктоза-обліпиха } \\
\text { «Обліпиховий вогник» }\end{array}$ & 37,08 & 10,6 & 2,50 & 31,0 \\
\hline $\begin{array}{c}\text { Контроль «Желейний формовий» } \\
\text { на Н-пектині }\end{array}$ & 68,0 & - & 0,86 & 26,0 \\
\hline $\begin{array}{c}\text { Н-пектин сахароза-червона } \\
\text { смородина }\end{array}$ & 41,64 & 15 & 1,1 & 25,8 \\
«Червоносмородиновий» & 42,42 & 11,54 & 1,1 & 24 \\
\hline $\begin{array}{c}\text { Н-пектин-глюкоза-гарбуз } \\
\text { «Сонячний» }\end{array}$ & 38,67 & 10 & 1,1 & 25 \\
\hline $\begin{array}{c}\text { Н-пектин-фруктоза-чорна } \\
\text { смородина «Чорносмородиновий» }\end{array}$ & 30,4 & 15,00 & 1,25 & 24,0 \\
\hline $\begin{array}{c}\text { L-пектин-сахароза-полуниця } \\
\text { «Полуничка» }\end{array}$ & 27,95 & 15,0 & 1,27 & 23,0 \\
\hline L-пектин -глюкоза «Малиновий» & 27,95 & 15,0 & 1,27 & 23,0 \\
\hline L-пектин-фруктоза «Ожиновий» & & & & \\
\hline
\end{tabular}

Міцність мармеладу традиційного желейного на Н-пектині складає 26 кПа, а мармеладу 3 пониженим вмістом сахарози - 25,8 кПа, глюкози -24 кПа, фруктози - 25 кПа. Міцність мармеладу на L-пектині з пониженим вмістом сахарози - 24 кПа, глюкози і фруктози - 23,0 кПа. Отже, оптимальні співвідношення рецептурних компонентів, можуть бути використані для розрахунку уніфікованих рецептур желейного мармеладу з пониженим вмістом цукрів.

Табличні дані рецептурного складу мармеладу дозволили додатково визначити показник глікемічності виробів і розрахувати їх енергетичну цінність (табл. 4).

Таблиця 4. Зміна показників глікемічності та енергетичної цінності розробленого мармеладу

\begin{tabular}{|c|c|c|c|c|}
\hline Назва & $\begin{array}{c}\text { Показник } \\
\text { глікемічності }\end{array}$ & $\begin{array}{c}\text { 3міни ПГ, } \\
\%\end{array}$ & $\begin{array}{c}\text { Енергетична } \\
\text { цінність }\end{array}$ & $\begin{array}{c}\text { Зменшення } \\
\text { ЕЦ,\% }\end{array}$ \\
\hline 1 & 2 & 3 & 4 & 5 \\
\hline $\begin{array}{c}\text { Контроль «Желейний } \\
\text { формовий» на агарі }\end{array}$ & 63 & - & 336 & - \\
\hline $\begin{array}{c}\text { Агар-сахароза-терен } \\
\text { «Терновий» }\end{array}$ & 43 & $-31,8$ & 249,1 & 25,9 \\
\hline $\begin{array}{c}\text { Агар-глюкоза-кизил } \\
\text { «Кизиловий» }\end{array}$ & 75 & +19 & 290,8 & 14,5 \\
\hline $\begin{array}{c}\text { Агар-фруктоза-обліпиха } \\
\text { «Обліпиховий» }\end{array}$ & 25 & $-60,4$ & 263,3 & 21,7 \\
\hline $\begin{array}{c}\text { Контроль «Желейний } \\
\text { формовий» на к-каррагінані }\end{array}$ & 63 & - & 332 & - \\
\hline $\begin{array}{c}\text { К-каррагінан-сахароза-кизил } \\
\text { «Кизилова насолода» }\end{array}$ & 43 & $-31,7$ & 251,9 & 24,2 \\
\hline $\begin{array}{c}\text { К-каррагінан-глюкоза-терен } \\
\text { «Лісова слива» }\end{array}$ & 73 & $+15,9$ & 284,5 & 14,3 \\
\hline
\end{tabular}




\begin{tabular}{|c|c|c|c|c|}
\hline & & & \multicolumn{2}{|c|}{ Продовження табл. 4} \\
\hline 1 & 2 & 3 & 4 & 5 \\
\hline $\begin{array}{l}\text { К-каррагінан-фруктоза-облі- } \\
\text { пиха «Обліпиховий вогник» }\end{array}$ & 24 & -62 & 241,7 & 27,2 \\
\hline $\begin{array}{c}\text { Контроль «Желейний } \\
\text { формовий» на Н-пектині }\end{array}$ & 62 & - & 321,8 & - \\
\hline $\begin{array}{l}\text { Н-пектин сахароза-червона } \\
\text { смородина } \\
\text { «Червоносмородиновий» }\end{array}$ & 45 & $-32,9$ & 258,8 & 19,6 \\
\hline $\begin{array}{c}\text { Н-пектин-глюкоза-гарбуз } \\
\text { «Сонячний» }\end{array}$ & 67 & +8 & 264,6 & 17,8 \\
\hline $\begin{array}{c}\text { Н-пектин-фруктоза-чорна } \\
\text { смородина } \\
\text { «Чорносмородиновий» }\end{array}$ & 25 & $-59,7$ & 239,7 & 25,5 \\
\hline $\begin{array}{c}\text { Контроль «Желейний } \\
\text { формовий» на Н-пектині }\end{array}$ & 62 & - & 321,8 & - \\
\hline $\begin{array}{c}\text { L-пектин-сахароза-полуниця } \\
\text { «Полуничка» }\end{array}$ & 45 & $-32,9$ & 231,4 & 28,1 \\
\hline $\begin{array}{c}\text { L-пектин -глюкоза } \\
\text { «Малиновий» }\end{array}$ & 68 & $+9,6$ & 266,4 & 17,3 \\
\hline $\begin{array}{c}\text { L-пектин-фруктоза } \\
\text { «Ожиновий» }\end{array}$ & 30 & $-51,7$ & 236,4 & 26,5 \\
\hline
\end{tabular}

Встановлено, що в усіх групах мармеладу відбувається зменшення енергетичної цінності. Так, для мармеладу желейного на агарі зменшення вмісту сахарози призводить до зменшення енергетичної цінності до 25,9\%, глюкози $14,5 \%$, фруктози - 21,7\%. Разом з цим в розробленому мармеладі з сахарозою i фруктозою на 31,8\% і 69,4\%, відповідно, зменшується показник глікемічності.

Для мармеладу желейного на к-каррагінані вилучення рецептурної кількості сахарози зменшує енергетичну цінність на $24,2 \%$, глюкози - на $14,3 \%$, фруктози - на 27,2\%. При цьому показник глікемічності для виробів 3 сахарозою зменшується на $31,7 \%$, 3 фруктозою - на $62 \%$.

В удосконалених рецептурах мармеладу з Н-пектином спостерігаються аналогічні залежності: в рецептурах із зменшеним вмістом сахарози і фруктози процент зменшення енергетичної цінності складає $19,6 \%$ і 25,5\%, а показник глікемічності зменшується на $32,9 \%$ і 59,7\% відповідно. В рецептурах мармеладу на L-пектині зменшення енергетичної цінності складає $28,1 \%$ для мармеладу з сахарозою, 17,3\% - для мармеладу з глюкозою і 26,5\% для мармеладу з фруктозою. Показник глікемічності при цьому зменшується на $32,9 \%$ - для сахарози і $51,7 \%$ - для фруктози. У рецептурах $з$ глюкозою показник глікемічності дещо зростає: на $8 \%$ — в мармеладі на Н-пектині і на 9\% в мармеладі на L-пектині.

\section{Висновки}

Наведені у статті дані свідчать про досягнення основної мети - оптимізації рецептурного складу мармеладу з пониженим вмістом сахарози (на $30,0 \%$ ), глюкози (на 30,5\%) і фруктози (на 32,0\%) за рахунок введення рівноцінної кількості полідекстрози; з різноманітними ягідними і овочевим пюре. При цьому енергетична цінність для всіх зразків в середньому знижена 
на 25\%, а показник глікемічності - для мармеладу 3 сахарозою на $32 \%, 3$ фруктозою - на 60\%. Розроблені нові види мармеладу желейного були відзначені на дегустаційних конкурсах. В установленому порядку галузевою Дегустаційною комісією були затверджені рецептури.

\section{Література}

1. Global action plan for the prevention and control of noncommunicable diseases. (2013). Geneva: World Health Organization. [Електронний peсурс]. - Режим доступу : http://apps.who.int/iris/bitstream/10665/94384/1/9789241506236_eng.pdf.

2. Finest Belgian Chocolate. (2018). [Електронний ресурс]. — Режим доступу : https://www.callebaut.com/ru-RU/шоколад/finest-belgian-chocolate.

3. Самая большая Премиум Коллекция Сладостей без содержания сахара и с низким содержанием углеводов. (2018). [Електронний ресурс]. - Режим доступу : http://www.lanouba-sugarfree.com/ru/.

4. Intervan. (2018). [Електронний ресурс]. — Режим доступу : http://www. intervan.es/ cafedry.php.

5. Walden Farms. (2018). [Електронний ресурс]. — Режим доступу : http:// sportivnoepitanie.ru/waldenfarms/

6. Наука про продукти харчування і технології. (2018). [Електронний ресурс]. Режим доступу : https://www.nestle.ua/randd/technologies

7. Fusaro D. (2016). Nestlé Scientists Create New Sugar Structure. [Електронний ресурс]. Режим доступу : https://www.foodprocessing.com/ industrynews/2016/nestle-creates-new-sugar/.

8. Гидроколлоиды. [Електронний ресурс]. - Режим доступу : https://www. cargill.com.

9. Стевия - медовая трава. Продукции натурального происхождения. Основной компонент — STEVIA. [Електронний ресурс]. — Режим доступу : http:// gudvil-invest.pulscen.com.ua.

10. Соловйова О.Л. Удосконалення технології желейного мармеладу спеціального споживання: автореф. дис. канд. техн. наук: 05.18.01. - Київ : НУХТ, 2011. - 159 с.

11. Аветісян К.В. Удосконалання технології двошарового желейного мармеладу з використанням крохмальних сиропів: дис. канд. техн. наук: 05.18.01. - Одеса : ОНАХТ, 2015. - $176 \mathrm{c}$.

12. Pavlović, Saša R., Tepić, Aleksandra N., Vujičić, Biserka L. (2003). LOW-CALORIE MARMALADES. APTEFF, 34, 23-30.

13. Кузнецова Л.С. Производство мармеладо-пастильных изделий / Л.С. Кузнецова, М.Ю. Сиданова. — Москва : ДеЛи Плюс, 2012. — 246 с.

14. Еркебаев М.Ж. Основы реологии пищевых продуктов / М.Ж. Еркебаев, Т.К. Кулажанов, Е.Б. Медведков. - Алматы : АТУ, 2006. — 298 с.

15. Imeson A. Food Stabilisers, Thickeners and Gelling Agents. — Wiley- Blackwell, 2010. $408 \mathrm{c}$.

16. Іоргачова К.Г. Технологія двохслойного дієтичного мармеладу / К.Г. Іоргачова, Л.В. Гордієнко, К.В. Аветісян // Біоресурси, біотехнологія харчових продуктів. — 2010. № $10 .-$ C. $24-26$.

17. Грабовська О. Вплив таутомерних перетворень глюкози на швидкість їі кристалізації / Н. Штангеєва, О. Грабовська, Н. Гордійчук, О. Качковський // Тези доповідей у збірнику наукових праць «Дні науки НаУКМА»: 10-а наукова конференція, 26-30 січня 2004 p. -2004 . - C. 13.

18. Камбулова Ю.В. Фруктові і желейні мармеладні маси з глюкозою / Ю.В. Камбулова, Д.С. Матяс, Н.О. Оверчук, Т.В. Федій // Збірник наукових праць ХДУХТ «Прогресивні техніка та технології харчових виробництв ресторанного господарства і торгівлі». 2017- № 1(25) - C. 256-270. 